\title{
Corporate Governance Code in Pakistan (2017): A Review
}

\author{
Naheed Sultan* \\ Department of Social Sciences, UK
}

*Corresponding author: Naheed Sultan, PhD Candidate, Department of Social Sciences, UK.

\begin{abstract}
This paper aims to analyse the current regulation of Pakistan in the field of corporate governance. The role of effective corporate governance in any developed or developing countries cannot be denied in terms confident investment and market stability. Pakistan first developed Code of Corporate Governance in 2002 and which got revised in 2012 and finally in 2017. Although the principles and practices of corporate governance are well developed in most parts of the world, however, the available literature on corporate governance issues in Pakistan is still not enough and there is a dearth of commentaries or analysis on the current regulation as being introduced in Dec 2017. Therefore, this paper aims to fill this gap through comparative approach, through documentary analysis, of the revisions to demonstrate the development process of Corporate Governance in Pakistan and to contribute to the ongoing debate on the effectiveness of new regulation.
\end{abstract}

Keywords: Corporate governance; Code; Pakistan

Abbreviations: SECP: Securities and Exchange Commission of Pakistan; CFO: Chief Financial officer; CEO: Chief Executive Officer; DTP: Directors training programme

\section{Introduction}

The issue of corporate governance and corporate accountability has become a centre of attention from the more that last two decades as a global challenge. ${ }^{1}$ However, in some emerging economies like Pakistan this concept is still not as developed as other parts of the world like UK ${ }^{2}$, USA ${ }^{3}$, South Africa ${ }^{4}$ and OECD principles of Corporate Governance ${ }^{5}$. Though, attempts have been made for the development of the code of corporate governance by the regulators and legislators with aim to attract more foreign investment to support Pakistan's economy and to meet global governance standards, but still need to be more competitive in these standards. ${ }^{6}$
Primarily derived from UK, USA and South African corporate governance Codes/Laws, the Code of Corporate Governance $2002^{7}$ (the code 2002) was enacted by Securities and Exchange Commission of Pakistan (SECP) which got revised as Code of Corporate Governance $2012^{8}$ (the code 2012) which eventually revised by SECP as Listed Companies (Code of Corporate Governance) Regulations 2017 (the Code 2017) $)^{9}$. Hence, the corporate governance regime in Pakistan include the Code 2017, the Companies Law 2017 and Pakistan stock Exchange Listing Rules. $^{10}$

\footnotetext{
'See ADRIAN CADBURY, REPORT OF THE COMMITTEE ON THE FINANCIAL ASPECTS OF CORPORATE GOVERNANCE 9 (1992).

${ }^{2}$ The UK Corporate Governance Code 2018.

${ }^{3}$ The Sarbanes-Oxley Act (2002), Pub. L. No. 107-24, 116 Stat. 745. (codified in sections of 11 U.S.C., 15 U.S.C., 18 U.S.C., 28 U.S.C., and 29 U.S.C.).

${ }^{4}$ The Kings Report IV on Corporate Governance for South Africa (2016), Institute of Directors SA,

${ }^{5}$ OECD (1999), Principles of Corporate Governance, Paris, OECD.

${ }^{6}$ Samza Fatima, Tom Mortimer, Muhammad Bilal, (2018) "Corporate governance failures and the role of institutional investors in Pakistan: Lessons to be learnt from UK", International Journal of Law and Management, Vol. 60 Issue: 2, pp.571-585

${ }^{7}$ The Code of Corporate Governance 2002, SECP. Pakistan.

${ }^{8}$ The Code of Corporate Governance 2012, SECP, Pakistan.

${ }^{9}$ The Listed Companies (Code of Corporate Governance) Regulations, SECP, Pakistan

${ }^{10}$ Ali Adnan Ibrahim, (2006) Corporate Governance in Pakistan: Analysis of Current Challenges and Recommendations for Future Reforms, 5 Wash. U. Global Stud. L. Rev. 323.
} 


\section{Corporate Governance Code 2017}

The Code 2017 is applicable to all listed companies or the companies which are required to comply with the code through their constitutions or licencing requirements. Moreover, this code amended, added some new ideas to the code 2012 instead of presenting a whole new regulation. The Code 2017 divided into fourteen chapters establishing rules mainly related to board of directors, their responsibilities, functioning and committees. Furthermore, emphasis is given to the role and responsibilities of directors along with their capabilities and professional development. The Code also outlined the rules regarding main executive offices like Chief Financial officer (CFO), Chief Executive Officer (CEO) and the Company Secretary.

\section{BODs Composition}

The Code 2017 has reduced the number of directorships to seven from five (the code 2012) excluding the directorship in listed subsidiaries ${ }^{11}$. This section is coinciding with the Companies Act 2017 which states that no person shall hold office as a director at the same time in more than such number of companies as may be specified ${ }^{12}$. Further, section 155 requires that a person holding the position of director in more than seven companies on the commencement of the Companies Act, 2017 shall ensure the compliance of this section within one year of such commencement. Independence of directors is being given more importance as compare to the code 2012, hence, it is must for the companies to have at least two or one third members as independent directors as compared to mandatory requirement of one independent director 13 .

Though the definition of independent directors has been excluded from the Code 2017. ${ }^{14}$ Moreover, they are required to submit a declaration of their independence as explained in the Act, in AGM of every financial year. The cross holding in case of links with other directors of charitable and not for profit organizations are being excluded to have any impact on independence of the directors. Introduction of at least one female director on the board is another positive step to bring gender balance in the BODs. ${ }^{15}$ Moreover, the code has changed the maximum number of executive directors from one third of the elected directors to one third of the elected board of directors. ${ }^{16}$ Separation of ownership and controlled in form of two separate offices of CEO and chairman of the board is continued in the code 2017 as in $2012^{17}$. However, the requirement from $\mathrm{CEO}$ to inform all the other directors about their role, responsibilities, power, remuneration, and entitlements, in the beginning of each director's new term is an addition to the Code. ${ }^{18}$

\section{BODs Functions}

The Code 2017 imposes fiduciary duties on BODs in more inclusive way that is not only towards the company and the shareholders but also to the stake holders. ${ }^{19}$ These responsibilities include:

a. Identification, management, policies, and implementation of effective internal controls for governance of risk.

b. Placement of effective, annual performance evaluation system for directors as well as for BODs itself.

c. Implementation of a formal code of conduct to promote ethical culture and to avoid any conflict of interest with the company.

d. To maintain complete record of key policies like HR policies, risk management, fee/remuneration of executive or independent directors or whistle blowing.

The related party transactions need to be presented before audit committee and to the BODs for review or approval according to the Act in special resolution. ${ }^{20}$ Directors training programme (DTP) from SECP approved institutes is continued with addition of $100 \%$ directors training up to 2021 with a new mandatory requirement of DTR for at least one female executive and one head of department every year from June $2019 .{ }^{21}$ All the directors are required to attend the AGM and for the meeting called for the conflict of interest of any directors the presence of at least two independent directors is mandatory.

\section{BODs Committees}

For the assistance and efficient use of BODs time two mandatory i.e. audit committee, and HR committee along with two non-mandatory committees i.e. nomination and risk management




committees are required by the code 2017.22 Audit committee is required to be composed of at least three members including non-executive directors and at least one independent director and should be chaired by independent director. "Financial Literacy" is the new condition introduced regarding the qualification of at least one member of the board. ${ }^{23}$ The Code 2017 requires CFO and the chairman not to attend the audit committee's meeting except requested. In contrary to the code 2012 the new code requires the circulation of meeting minutes to CFO only if required not as compulsion as is the previous code..$^{24}$

HR and remuneration committee which was encouraged in the code 2012 is now mandatory in the code 2017 which is required to meet at least once in a year and chaired by an independent director. Like audit Committee CEO and the Chairman are excluded from $\mathrm{Hr} \& \mathrm{R}$ meeting except required. The terms of reference are to be determined by the BODs. ${ }^{25}$ Nomination and risk management committees are non-mandatory and new requirements of the Code 2017. The composition and terms of reference are left for the BODs to determine and decide for these committees except some for risk management committee like internal control monitoring, risk mitigation and disclosure of company's risk policies. ${ }^{26}$

\section{Chief Offices of a company}

Moreover, the code 2017 explained the function and requirements of the main executive offices of a company like chief financial officer (CFO), company secretory, and head of internal audit. BODs are responsible for appointment and removal of these executive officers except the head of internal audit can only be removed by the recommendation made by the audit committee. ${ }^{27}$ The eligibility criteria for appointment of CFO and head of internal audit have been amended in the new code which requires experience from three to seven years depending upon the membership of any professional body of accountants established, managed or recognised by Pakistan. ${ }^{28}$ No person shall be appointed as the Company Secretary unless he holds the qualification as specified under the relevant regulation $\mathrm{s}^{29}$ by the SECP. ${ }^{30}$

Hence, this code is based on 'comply or explain'31 principle, thus, gives the right to the companies to apply for relaxation of the rules to SECP in case of non-compliance with fee and reasons for such non-compliance. If deems fit, SECP can relax the rules for the request. ${ }^{32}$ The code 2017 states the non-compliance of this code the penalties will be determined according to the Act 2017 which states that a contravention of any regulation shall be punishable with a penalty which may extend to Rs 5 million and, where the contravention is a continuing one, with a further penalty which may extend to Rs 100,000 for every day after the first during which such contravention continues ${ }^{33}$ [1-5].

\section{Conclusion}

In conclusion, the development of corporate governance regulation in Pakistan is still ongoing which is evident from the reforms done in the last sixteen years. However, the development in regulations and legislation will be of less use if seriousness will not be exhibited for its implementation by rejecting box ticking approach by the companies. Moreover, the convergence of corporate governance rules should only be done in context of social and business environment of Pakistan to be competitive globally (Table 1).

Table 1: Corporate Governance Code 2002, 2012, 2017 in a glance. (developed by researcher)

\begin{tabular}{|c|c|c|c|c|}
\hline NO & Issues & CCG 2002 & CCG 2012 & CCG 2017 \\
\hline $1-$ & $\begin{array}{l}\text { Director's } \\
\text { Independence }\end{array}$ & $\begin{array}{l}\text { Voluntary provision for at least one } \\
\text { independent director in BODs }\end{array}$ & $\begin{array}{l}\text { Mandatory provision for one NED is board } \\
\text { with the preference of } 1 / 3 \text { NEDs in BODs }\end{array}$ & $\begin{array}{l}\text { Mandatory provision for two or } 1 / 3 \\
\text { NEDs in BODs whichever is higher }\end{array}$ \\
\hline $2-$ & $\begin{array}{l}\text { Independence of } \\
\text { NEDs }\end{array}$ & $\begin{array}{l}\text { Independence was not well defined } \\
\text { i.e should not be the holding } \\
\text { the directorship of ten other } \\
\text { companies. }\end{array}$ & $\begin{array}{l}\text { Defined the independence of NEDS is } \\
\text { defined more extensively } 1 \text { (b) }\end{array}$ & $\begin{array}{l}\text { Definition of independence taken out } \\
\text { from the Code and added in the Act } \\
2017 \text {. } \\
\text { - Annual declaration of } \\
\text { independence, as required by the Act, } \\
\text { by the NEDs. }\end{array}$ \\
\hline
\end{tabular}

${ }^{22}$ The Code 2017, Chapter X

${ }^{23}$ The Code 2017, Chapter X, sec 28(c)

${ }^{24}$ Ibid sec: 28 (2c).

${ }^{25}$ The Code 2017, Chapter X, Sec 29

${ }^{26}$ The Code 2017, Chapter X, sec 30-31

${ }^{27}$ The Code 2017, Chapter VIII, section 21-22.

${ }^{28}$ Sec: $23-24$

${ }^{29}$ The Companies (General Provisions and Forms) Rules, 1985, Rule 14 (B).

${ }^{30}$ Sec: 25

${ }^{31}$ Higgs Report (2003)" REVIEW OF THE ROLE AND EFFECTIVENESS OF NON-EXECUTIVE DIRECTORS”, London: Department of Trade and Industry, 1.14, at 16. ("Listed companies have to report on how they apply the Code's principles and to state whether they comply with the detailed provisions and, if not, why not. This approach has worked well.").

${ }^{32}$ Sec: 42

${ }^{33}$ The Companies Act 2017, Sec 512(2). 


\begin{tabular}{|c|c|c|c|c|}
\hline $3-$ & $\begin{array}{l}\text { Executive } \\
\text { Directors } \\
\text { (Modification in } \\
\text { content not in } \\
\text { implication)* }\end{array}$ & $\begin{array}{l}\text { Should not be more than } 75 \% \text { of } \\
\text { elected directors including CEO }\end{array}$ & $\begin{array}{l}\text { Cannot be more than } 1 / 3 \text { of the elected } \\
\text { directors including CEO }\end{array}$ & No Change \\
\hline 4- & $\begin{array}{l}\text { Number of } \\
\text { directorships }\end{array}$ & $\begin{array}{l}\text { The directorship for } 10 \text { listed } \\
\text { companies is allowed. }\end{array}$ & $\begin{array}{l}\text { Directorship is limited to } 7 \text { listed } \\
\text { companies except listed subsidiaries. }\end{array}$ & $\begin{array}{c}\text { Directorship is reduced from } 7 \text { to } 5 \\
\text { including alternate director of more } \\
\text { than 5. Subsideries are excluded from } \\
\text { allowance. }\end{array}$ \\
\hline $5-$ & $\begin{array}{l}\text { Gender Balance in } \\
\text { BODs }\end{array}$ & No Clause & No Clause & $\begin{array}{l}\text { Mandatory to have at least one Female } \\
\text { director in BODs. }\end{array}$ \\
\hline 6- & Board Evaluation & No Clause & $\begin{array}{l}\text { Board shal put in place a mechanism of } \\
\text { performance annual evaluation of board }\end{array}$ & $\begin{array}{l}\text { Annual evaluation of board's } \\
\text { performance is mandatory. }\end{array}$ \\
\hline 7- & $\begin{array}{l}\text { Office of chairman } \\
\text { and CEO }\end{array}$ & $\begin{array}{l}\text { The Chairman of a listed company } \\
\text { shall preferably be elected form } \\
\text { among the nonexecutive directors } \\
\text { of the listed company. (voluntary) }\end{array}$ & $\begin{array}{l}\text { The Chairman shall be elected from } \\
\text { amongst the non-executive directors of the } \\
\text { listed company. (mandatory) Separation of } \\
\text { office of CEO and Chairman, so cannot be } \\
\text { one person. }\end{array}$ & $\begin{array}{l}\text { Election of CEO will be done as per } \\
\text { The Act } 2017 \text {. }\end{array}$ \\
\hline 8- & $\begin{array}{l}\text { Directors Training } \\
\text { Programme (DTR) }\end{array}$ & $\begin{array}{l}\text { Mandatory to provide DTR from } \\
\text { institutes that meets the criteria } \\
\text { of SECP. }\end{array}$ & No change. & $\begin{array}{l}\text { Revised A } 100 \% \text { DTR trained } \\
\text { directors target is set by } 2021 . \\
\text { Additionally, a mandatory training } \\
\text { for female executives and head of } \\
\text { departments is proposed. }\end{array}$ \\
\hline 9- & $\begin{array}{l}\text { Appointment } \\
\text { and removal and } \\
\text { qualification } \\
\text { criteria for } \\
\text { Chief Financial } \\
\text { Officer (CFO) } \\
\text { and Company } \\
\text { Secretary (CS) }\end{array}$ & $\begin{array}{l}\text { Appointment, remuneration } \\
\text { and terms and conditions of } \\
\text { employment of CFO and CS } \\
\text { determined by CEO and approved } \\
\text { by Board. The same mechanism } \\
\text { followed for removal. }\end{array}$ & $\begin{array}{l}\text { The appointment, remuneration and terms } \\
\text { and conditions of employment of the CFO, } \\
\text { CS and the Head of Internal Audit (IA) of } \\
\text { listed companies shall be determined by } \\
\text { the Board. The removal will also be by the } \\
\text { Board for CS and CFO. }{ }^{*} \text { To ensure their } \\
\text { discharge of duties without any executive } \\
\text { influence. }\end{array}$ & No change \\
\hline $10-$ & $\begin{array}{l}\text { The Head of } \\
\text { Internal Audit (IA) }\end{array}$ & No Clause & Qualification introduced for Head of IA. & $\begin{array}{c}\text { Specific eligibly criteria are been } \\
\text { set as membership of recognised } \\
\text { accountancy body and experience } \\
\text { from } 3 \text { to } 7 \text { years. }\end{array}$ \\
\hline 11- & $\begin{array}{l}\text { Director's } \\
\text { remuneration }\end{array}$ & No Clause & $\begin{array}{l}\text { Director's (Executive and NEDs) aggregate } \\
\text { remuneration shall have to be disclosed } \\
\text { in annual report through formal and } \\
\text { transparent procedure. }\end{array}$ & $\begin{array}{l}\text { In addition to disclose the } \\
\text { remuneration policies and details } \\
\text { in annual reports companies are } \\
\text { encouraged to post key features on } \\
\text { website. }\end{array}$ \\
\hline $12-$ & Board Committees & $\begin{array}{c}\text { Audit Committee: } \\
\text { Reporting Procedure: } \\
\text { The Audit Committee of a listed } \\
\text { company shall appoint a secretary } \\
\text { of the Committee. }\end{array}$ & $\begin{array}{l}\text { Audit Committee: The Chairman of the } \\
\text { audit committee shall be an independent } \\
\text { director, who shall not be the chairman of } \\
\text { the board. Audit Committee shall comprise } \\
\text { of nonexecutive directors. } \\
\text { Human Resources and Remuneration } \\
\text { Committee introduced. }\end{array}$ & $\begin{array}{c}\text { Chairman of Audit Committee and HR } \\
\text { committee should be an independent } \\
\text { director. An audit committee is to } \\
\text { include at least one member who is } \\
\text { "financially literate" } \\
\text { Added two more non mandatory } \\
\text { Committees } \\
\text { Risk Committee } \\
\text { Nomination committee }\end{array}$ \\
\hline 13- & The Internal Audit & $\begin{array}{c}\text { There shall be an internal audit } \\
\text { function in every listed company. } \\
\text { The head of internal audit shall } \\
\text { have access to the chair of the } \\
\text { Audit Committee. }\end{array}$ & $\begin{array}{l}\text { The internal audit function can be } \\
\text { outsourced by a listed company, to a } \\
\text { professional services firm or be performed } \\
\text { by the internal audit staff of the holding } \\
\text { company. In the event of outsourcing the } \\
\text { internal audit function, the company shall } \\
\text { appoint or designate a fulltime employee } \\
\text { other than the CFO, as Head of Internal } \\
\text { Audit, to act as coordinator between the } \\
\text { firm providing internal audit services and } \\
\text { the board. }\end{array}$ & No change. \\
\hline $14-$ & $\begin{array}{l}\text { Compliance of the } \\
\text { Code }\end{array}$ & No Clause & No Clause & $\begin{array}{l}\text { Penalty provision for noncompliance } \\
\text { with the regulations has been added } \\
\text { according to the Act } 2017 \text {. }\end{array}$ \\
\hline
\end{tabular}




\section{References}

1. Ali Adnan Ibrahim (2006) Corporate Governance in Pakistan: Analysis of Current Challenges and Recommendations for Future Reforms, 5 Wash. U. Global Stud. L. Rev 5(2).

2. Cadbury A (1992) Report of the Committee on the Financial Aspects of Corporate Governance, London: Gee \& Company 2(4).

3. Higgs Report (2003) Review of The Role and Effectiveness of NonExecutive Directors", London: Department of Trade and Industry.

4. OECD (1999) Principles of Corporate Governance, Paris, OECD.

5. Samza Fatima, Tom Mortimer, Muhammad Bilal (2018) Corporate governance failures and the role of institutional investors in Pakistan Lessons to be learnt from UK. International Journal of Law and Management 60(2): 571-585.

\section{(C) This work is licensed under Creative}

To Submit Your Article Click Here:

DOI: $10.32474 /$ PRJFGS.2019.03.000153

\section{Codes}

1. Listed Companies (Code of Corporate Governance) Regulations, 2017.

2. The Code of Corporate Governance 2002, SECP. Pakistan.

3. The Code of Corporate Governance 2012, SECP. Pakistan.

4. The UK Corporate Governance Code 2018.

5. The Kings Report IV on Corporate Governance for South Africa (2016), Institute of Directors SA.

6. The Sarbanes-Oxley Act (2002), Pub. L. No. 107-24, 116 Stat. 745.



